\title{
Governing in a time of global crises: the good, the bad, and the merely normal
}

\section{B. Guy Peters ${ }^{1}$}

Received: 27 December 2020 / Accepted: 25 January 2021 / Published online: 25 February 2021

(c) The Author(s), under exclusive licence to Institute for Global Public Policy, Fudan University 2021

\begin{abstract}
Governments and societies in 2020 and 2021 have been facing three interconnected crises-COVID-19 and the health crisis, an economic crisis resulting from the health crisis, and a social crisis around inclusion and equity. The magnitude of these crises, and their nature, vary across countries, but no country has been left untouched. The governance responses to these crises have varied markedly, both in terms of their character and their success. This paper discusses the good, the bad, and the merely normal aspects of governance that have emerged in response to these crises.
\end{abstract}

Keywords Governance · Crisis · Inclusion · Planning · Policy failure · Political extremism

\section{Introduction}

Governance is not easy in the best of times. The tasks involved in delivering public services, regulating the activities of individuals and organizations, and coping with a potentially hostile environment place significant demands on any set of wouldbe governors. Those demands are exacerbated when governance confronts a crisis, whether it is the product of natural causes or caused by humans. Governments in 2020 and 2021 have been facing at least three crises which are to some extent interconnected and all of which place major strains on governance capacities of the public sector. As students of governance, however, we can use these extremely dire events to better comprehend how governance functions, and what may be done to increase governance capacities.

Communicated by Yijia Jing.

B. Guy Peters

bgpeters@pitt.edu

1 Maurice Falk Professor of Government, University of Pittsburgh, Pittsburgh, USA 
The first and most obvious crisis is that related to the COVID-19 pandemic and the huge loss of life and health associated with that disease. The need to marshal health care personnel and equipment, control the movement and gatherings of citizens, and foster research to develop cures and/or vaccines for the disease has strained the governance capacity of all contemporary governments. And those elements of the crisis have also demonstrated the need for collaboration between the public and the private sectors in addressing any significant crisis, meaning that more interactive forms of governance are also evolving to deal with the crisis.

The pandemic has produced a major economic crisis in most countries. The mechanisms used to control the spread of the disease have had very negative effects on economic activity, and the fear associated with the virus has further slowed economies. Millions of people are out of work, or working reduced hours, and even in well-functioning welfare states the economic downturn is causing immense human misery and exacerbating underlying problems of economic and social inequality (Nassif-Pires et al. 2020). The effects on citizens in less affluent regimes are all the more devastating. And that economic downturn and the revenue losses associated with it are producing fiscal problems for the very governments that are attempting to manage the pandemic and the economic problems.

The above two governance problems have been animated fundamentally by an issue of public health, but in many parts of the world they are combined with social problems that are long-standing and may be even more difficult to address successfully. In the United States and in some other countries these social problems are manifested in terms of race, while in many parts of Europe the problems are manifested as reactions to large-scale immigration. These social issues have been exacerbated by the pandemic, as people of color generally have significantly higher morbidity and mortality rates from COVID-19 than do white or native-born citizens (APM 2020). Further, people of color and immigrants tend to have suffered differentially from the economic slowdown associated with the pandemic.

Compared to these problems of social exclusion and inequality the issues of public health and the economy are relatively simple. Race and inclusion may be truly wicked problems (Peters), with complex interactions among variables, multiple sources of causation, and no clear solution. The contemporary period then constitutes a "perfect storm" that poses immense and interconnected governance challenges. Any government, along with its social partners, confronting these issues will require an extremely high level of capacity, as well as the political will to utilize that capacity. And these interconnected crises also remind us how important governability is, given that compliance by members of the society is essential for making the necessary public health measures function effectively (see Werron and Ringe 2020). Thus, contemporary governance will be characterized by high levels of interaction between the public and the private, the investment of large amounts of "political capital", and the need to mobilize the governance resources of society as well as those of government toward reaching a clear but difficult goal.

These rather obvious crises in society may also be related to a more subtle problem threatening the society and polity. This problem began manifesting itself before these other crises began, but has conditioned the responses of governments and of individuals, to the more obvious crises. I am referring to the spread of populist 
politics and with it the "post-truth" style of politics. It is difficult to argue that populism per se is not a viable political ideology, albeit a rather thin one (Vieten 2020). The problem is that contemporary populism on both the right and the left has been associated with a rejection of rationalist epistemologies in favor of making policies based on beliefs and outright untruths (see Rauch 2018, 2020).

The emergence of the post-truth version of governance is especially paradoxical in light of the emphasis on evidence-based policymaking, both in the literature of public policy and in the practice of many governments (Cairney 2016). It is also paradoxical given the explosion of knowledge and the general availability of information about policy issues on the internet. We live in an age in which governments have unprecedented capacity to apply knowledge and experience to human problems but many choose to follow their own unsubstantiated beliefs or urban myths. ${ }^{1}$

The combination of genuine crises affecting health and the economy, and epistemic crises facing governments, and the society more generally, does not provide a promising environment for contemporary governance. Especially when there are other major problems to address, most notably the climate crisis. What are the possibilities for governing in this complex and perilous environment? And what can both would-be governors and citizens do to cope more effectively with these challenges? It would be easy to say that the cause is lost and all we have to look forward is a declining quality of governance incapable of addressing serious problems. But is the reality actually that dire?

I will be arguing that some of the emerging realities for governance may be undesirable indeed, but at the same time there are opportunities for enhancing the future quality of governance assuming the right choices are made in response to the pandemic. In addition, much of governing will remain very much like it was before these crises. At times like these, it is easy for analysts to emphasize the exceptional and to ignore the rather ordinary yet crucial aspects of governing that must be done if government, and its society, are to be successful. And it may also be easy for governments to forget those quotidian aspects of governance as well as they pursue grand schemes for addressing the crises.

In examining the way in which governance has evolved during the time of these several crises, it is important to note that there are marked differences in the ways in which countries have addressed the problems. Some of these differences are based on the structure of government, perhaps especially the level of decentralization of government (Peters and Grin, forthcoming). Other differences may be a function of culture and beliefs, including beliefs about the role and efficacy of government (Bouckaert et al. 2020). Still others may be a function of the extent to which governance is dependent upon relationships with social actors.

In times of crisis much of the action of governing reverts to government as the source of authority within the society. Citizens see their government as the source of response to the crisis and expect, or indeed demand, that something is done. That does

\footnotetext{
1 President Trump's approach to the pandemic is a clear example of relying on those myths and unscientific approaches, with disastrous consequences. There is a huge volume of information on the internet, but the major task remains sorting and evaluating that information.
} 
not mean that the social actors are excluded from involvement in the responses, but it does mean that governments are expected to do most of the steering, and to provide clear direction to those social actors and to citizens. Even when there is in general little confidence in the institutions of government the public may expect them to take charge during a crisis and to provide the governance that is needed.

This paper will reflect my location in the United States, and observing the pandemic and these other crises in perhaps their worst manifestation. While the crises are more severe the reactions-both good and bad-have also been perhaps the most instructive. I will when possible also provide some comparative analysis as an aid to understanding the interactions of crisis and existing social, economic and political institutions. The comparisons included will be far from systematic, but should still be useful for understanding how crises can alter governance-in the short term and for the longer term.

\section{The Bad}

Given the current Zeitgeist, it seems appropriate to begin with the threats to governance that are being posed by the pandemic, and the conjuncture of other crises. There is ample gloom about governance to consider, but there are several particularly important ways in which these crises have affected governance, and may continue to affect governance for some time. For the most part, these challenges to governance have merely exposed undercurrents in the polity and the society that have been present for decades. But in some cases, the challenges are more specific, especially when the health and economic crises coincide with the post-truth nature of some contemporary political discourse.

\section{Political extremism}

A crisis, and especially the simultaneous occurrence of several crises, can open the door for political extremists, and for extreme solutions to the problems arising from those crises. The Great Depression, for example, facilitating the rise of fascism in Europe, as well as less consequential extremists such as Huey Long in the United States (Gillon 2018). And the emergence of crisis also may activate the extreme tendencies of seemingly more moderate political leaders. The literature on crisis management points to the importance of "keynoting", or the capacity of leaders to frame a crisis situation (Schneider 2011). Providing simple solutions to complex problems is an effective strategy for political extremists, and in crises the public is willing to accept any solution, a pattern that is conducive to greater democratic backsliding (see Levitsky and Ziblatt 2018). The attacks on the US Capitol on January 6, 2021 is perhaps the clearest example of this governance issue.

\section{Decline of institutions}

The need to address these crises through political means, and often rather extreme political means, has been associated with a declining trust in institutions. And in 
addition, some institutions have been forced to change in the short-term in ways that may undermine their longer-term effectiveness. In some countries, the apparent (if not always real) failures of healthcare institutions have prevented more effective responses. And in dealing with the economic crisis central banks have apparently become more politicized. While perhaps functional for dealing with this crisis that may damage the long-term effectiveness of economic management.

In addition to the democratic backsliding that can be associated with political crises, the complex causal relationships that may be associated with the crisis may provoke simplistic solutions that will actually delay any effective resolution of the underlying issues. In the case of COVID-19, the cause and effect relationship underlying the pandemic is very clear-exposure to the virus causes the illness. Likewise, the ultimate solution for the pandemic-the vaccine-is clearly identifiable if more difficult to the product. The dangers arose when various quack cures were proposed-generally by political extremists and /or grifters-that divert attention from more productive yet less exciting responses-social distancing and wearing masks.

The governance of the pandemic, and even the economic crisis associated with it, does not involve confronting a "wicked problem". Rather, the cause and effect relationships are clear, as are the solutions, and an array of short-term ameliorative policies. Crises associated with truly wicked, or "super-wicked" problems (Levin et al, 2012) may also evoke extreme responses, with the most common being denial. In these cases, however, when solution if not cause are less clear and less easily implemented, the appeal of the quick, easy and generally incorrect solutions offered by extremists or grifters will be even more appealing. Contemplating, and then attempting to address, a truly wicked problem is difficult and often requires long-term and painful solutions. Denial, or a placebo, are much more palatable. As President Biden pointed out in his inaugural address, truth has been one of the victims of these crises.

Politics surrounding the COVID-19 crisis has in some countries such as the United Kingdom and the United States, resembled those that one might expect from a truly wicked problem. Rather than quickly moving toward well-known public health measure to contain the spread of infection governments engaged in denial and shifting the blame (see Hood 2011). Crises, like many other governance situations, are poltiically and socially constructed, and governments may find it in their own best interest to make the problem appear as difficult as possible to avoid culpability for failures.

\section{Nationalism}

A final negative consequence of attempting to govern during the crisis has been the increase of nationalism and the loss of commitments toward a broader global society. This nationalism has been expressed most vehemently against migrants and refugees but has been expressed even within the European Union, where border controls have gone up and free passage within the Schengen area has been diminished. The fear of contagion from migrants has added to the existing welfare state nationalism, attempting to preserve social benefits only for native members of the community. The development of the vaccines to contain the virus has if anything 
heightened the extent of the nationalism, as every country attempts to secure sufficient doses for its citizens at the expense of others (Hafner et al. 2020). This version of nationalism will, of course, affect the poorest countries of the world most severely (Wintour 2021).

In short, governance in the midst of crisis has exposed weaknesses in the ways in which governance is often conducted and more importantly has politicized governance in areas which had been left in the hands of professionals and their institutions. While politicians naturally want to control governance when they inevitably will be held accountable for the results, this declining insulation of institutions, and the declining respect for the expertise held within those institutions may have negative long-term consequences for governing.

\section{Paradoxes of governance in a time of crisis}

The various governance problems that have manifested themselves during this time of the several simultaneous crises, and the negative consequences of those crises, point to several paradoxes about governing, and especially about governing in a time of extreme stress on governance capacity. These paradoxes reflect both the reactions of citizens to the actions of their governments, as well as the actions of those charged with attempting to provide governance. And, in general, the paradoxes point to the ways in which citizens and the institutions of governance interact to provide more or less effective steering and control within society during bad times as well as good.

The first and most obvious paradox arising from the pandemic is that citizens appear to expect effective and efficient service in the crisis that they assume will not perform well dealing with more mundane governance challenges. This paradoxical reaction to the pandemic has been especially evident in the United States and to some extent in other Anglo-American countries that tend to be skeptical about government. This reaction has not, however, been confined to those cases. This behavior may actually express more underlying confidence in institutions than they are willing to express in normal times, but it also demonstrates the extent to which crisis governance is crucial for building trust in government. This may reflect a general decline in public trust in the public sector (Norris and Englehart 2019).

A second and related paradox is that crises always appear unexpected even though they appear with alarming frequency. Even though governments have created more emergency response organizations and appear to have enhanced their capacities in responding to emergencies, each new crisis appears to create surprise and require rethinking of the appropriate responses. Like generals, governments despite their efforts at planning, appear to be fighting the last war again and generally doing so unsuccessfully. This observation then should be a signal to focus on resilience and adaptability in designing governance (Chandler 2014).

And finally, the very institutions and actors that are most important to respond to crises appear to be those that are most undermined by crisis. In the pandemic institutions such as the World Health Organization and the Center for Disease Control and Prevention in the United States have had their reputations tarnished, as did the 
European Central Bank during the Great Recession. This is to some extent to be expected when the governance outcomes are not what citizens hope for, or expect, but at the same time attempts to denigrate these institutions, and the need to respond, may divert attention from actually coping with the crises at hand. ${ }^{2}$

\section{The Good}

The governance difficulties created by the crisis are rather easy to identify and tend to occupy a good deal of space in the media. We should, however, be aware that crisis, or any other shock to the existing system, can also produce benefits. These crises are no different, and despite the numerous problems created there have been some benefits. Some of those benefits will be short-lived and will likely vanish as soon as the virus does, but others may be enduring, and may alter policy and governance in some countries in very profound ways.

Fostering Innovation. Crises expose the weaknesses of existing political and economic arrangements, and can produce demands for change. The historian Corelli Barnett (1986) described this exposure to crisis as "The Audit of War" with reference to weaknesses in British governance before and during World War II, and the same auditing process has taken place in less extreme situations. Even relatively minor "disasters" such as a poor response to a heavy snowstorm by a city government can be used to assess just how well those institutions of governance are functioning.

Some major innovations in governance have been born out of the necessities imposed by the crisis. The expansion of the welfare state in a number of countries grew out of the deprivations of wars and depressions. This was perhaps clearest in the United States where the "New Deal" of President Franklin Roosevelt launched a number of social and economic programs, some like Social Security which continue to this day. The economic and social crisis of the Depression enabled the president to overcome the basic conservatism of Americans to launch interventions designed to ameliorate the suffering of millions of citizens.

More recently, the Great Recession led to the development of new instruments for economic policy notably quantitative easing. The idea for this intervention was not really new, but the economic crisis created possibilities for using the tool that would not have arisen in normal times. This instrument has now become another widely used tool in the armamentarium of governments seeking to manage their economies. We could add to this list of innovations in governance that have emerged from crisis, real or perceived, but the basic point remains that the need to address fundamental governance problems can open the door for innovation.

The current crises have as yet not produced those major innovations in governance, but they have raised questions about important policy changes in a number of countries. In the United States, the pandemic has increased interest in a more

\footnotetext{
2 This was certainly true for the Federal Emergency Management Agency during its rather catastrophic response to Hurricane Katrina in New Orelans (Cooper and Block 2007).
} 
comprehensive national health care program, one that would integrate existing programs such as Medicare, Medicaid and the Affordable Care Act (Obamacare). The current patchwork of programs is proving inadequate for coping with the pandemic, and it is becoming more apparent that something new is needed (Galvani et al. 2020).

Among European countries, the possibilities of creating something like a guaranteed income for the population appears more possible after the pandemic. The widespread lockdowns around the Continent, with governments replacing a significant percentage of the income lost by workers and businesses may be creating a new chapter in the history of the welfare state. The need for such massive interventions into the economy will, with good fortune, be short-lived but the idea that the population should have a clear guarantee of income now appears feasible, ${ }^{3}$

\section{Activating institutions}

As well as fostering innovation crises may activate and help reform older institutions. Institutions may be dormant or slide into apparent obsolescence but may still be available when needed in times of crisis. There are two notable examples that are apparent from the contemporary crises. The first is more general, albeit still variable across countries. Much of the investment of personnel and other resources in health care has, over the past several decades, gone into curative medicine, and especially into ${ }^{4}$ the hi-tech medicine practiced in tertiary health care institutions. Although extremely valuable, the hi-tech approach to medical care has been challenged by critics as diverting attention from more basic medicine, and individual responsibility for health (Ehrenreich 2018). In the current pandemic rather old-fashioned public health measures have been more important in stemming the tide of infection, although the high medicine has been crucial for treating those who fall ill.

The second example of institutions being activated is federalism, especially in the United States but also to some extent in other federal systems (Peters and Grin, forthcoming). As already noted to be successful the fight against the pandemic involved vertical as well as horizontal coordination. But that vertical coordination assumed that there would be active sub-national governments attempting to solve some of the problems posed by COVID-19 themselves. The American case was one of activation of the sub-national governments largely because of the inaction of the federal government.

That initial phase of "opportunistic federalism" (Conlan 2006) played mainly by Trump administration, the creation of the vaccine and the need for cooperation in distributing it returned the system to a more cooperative form of federalism. The federal government was responsible for the purchase of the vaccine and the distribution of the vaccine to the states. The states and then localities were responsible for

\footnotetext{
${ }^{3}$ Finland has already carried out an experiment of this sort in less troubled times, finding that although the program did little to alter economic behavior, it did create security and greater happiness among the population (New York Times 2019).

${ }^{4}$ For a somewhat extreme version of this analysis see Garrett (2000).
} 
making decisions about allocation to individuals and for actually administering the shots-often with the cooperation of private firms such as pharmacies. At least in the first instance this system has worked, and the entire period of coping with the pandemic has put the states back into a more central position in the policy.

\section{More fundamental change}

Finally, and more speculatively, the pandemic and the other associated crises may be able to foster more fundamental changes in governance. It has become clear to many people that the conventional wisdom of neo-liberalism may not be as successful in governing as many advocates would like to believe. The question increasingly has become not the size of government, as massive amounts of money are being spent on health care, as well as to keep the public at least minimally solvent during these crises. The question has become the quality of governance, and that quality has been found to be sorely lacking in many cases (see Gaskell and Stoker 2020).

As well as some increased emphasis on the quality of governance, and on public governance in general, these interrelated crises may also require some greater thinking about equality and inclusion. These health crises may had a disproportionate impact on poor, minority and immigrant populations, as has the economic crisis resulting from the health crisis. These inequalities are hardly new but they have become more apparent during the pandemic. The effects of social and economic inequalities have become evident and measurable in terms of lives lost, and hence creating more inclusive forms of governance may become more possible as a result of the pains of these crises (Peters 2020).

\section{The merely ordinary}

As noted above, these interrelated crises in governing in 2020 have demonstrated that some of the issues we encounter in governing on a regular basis are exaggerated and magnified during the crisis. Ordinary governance must go on, but it and crisis governance can inform and improve one another. These several crises confronting the public sector and its allies then serve to emphasize some old "chestnuts" in the study, and practice, of governance, and to make us aware of the need to build governance capacity even in "normal" times.

\section{Coordination}

Coordination is perhaps the most relevant of the "ordinary" governance tasks that must be emphasized during the current crisis. Especially within the health crisis there were a number of compelling needs for coordination, both horizontally and vertically. While much of the focus has been on acute care in hospitals, other varieties of health services are also important for coping with this one crisis, notably public health. And social services and even the protective services are important for 
gaining compliance and shielding the most vulnerable segments of the population from exposure.

The coordination demands are not just horizontal, however, and there has been a need to link national-level governance in the health domain with trans-national and sub-national health organizations. The World Health Organization served, at least early in the crisis, as a clearing house of information and a monitoring organization for governments around the world. In Europe the European Union-although lacking a specific competence in health-also has served to coordinate some aspects of the national responses to COVID-19 (Pacces and Weimer 2020).

In federal regimes particularly coordinating activities between the central government and sub-national governments, as well as among the sub-national governments, was crucial for any success of the collective response (Abrucio. et al. 2020; Peters and Grin, forthcoming). The importance of coordination is especially evident when the principal competence for health policy rested in those sub-national governments (Wolf-Fordham 2020). In the United States, for example, much of the extreme failure of response to the crisis can be laid to the failure of levels of government to work together effectively, compounded by the relative indifference of the Trump administration to the problem.

The coordination of vertical coordination of actors is less important when dealing with the economic crisis, given the dominance of federal financial powers. But even then the failure of the central government to act may induce sub-national governments to act to attempt to assist their citizens in difficult times (National Governors Association 2020). And the coordination among economic actors, and between fiscal and monetary policy, is likewise essential for effective responses to the current economic crisis. Coordination may be more difficult in crisis, given the need for swift action and the opportunities for playing bureaucratic politics, but it remains as important as ever for success.

\section{The interconnections of problems}

Just as there is a need to make the responses of governance systems to crisis coordinated, the problems themselves are connected and interact. Again, this is true for more mundane policy problems but the connections become more apparent and more destructive in times of crisis. In this case, the health crisis clearly caused the economic crisis, but that economic crisis feeds back into the health crisis. People who have been made unemployed may be willing to take jobs with a high risk of infection simply because they need the money, and the spread of the virus continues. And the pandemic tends to exacerbate not only economic inequality but also educational inequality as students with less parental support and less adequate connections to remote learning technology fall further behind (Bellafante 2020).

Most governments are divided into "silos" which mean that not only are responses to problems divided by subject matter or clientele, but even the perception of the problems may be segmented. The need for coordination is discussed below, but the problem of problem definition is perhaps even more pervasive, and more difficult (see Peters 2018). Perceiving interconnected problems is relatively easy when crises 
make them so visible, but the same connections between health and the economy may exist in normal times without receiving the attention that they deserve. ${ }^{5}$

\section{Governance at the street level}

The contemporary crises have emphasized the need to be able to govern at the street level. The lowest echelons of government are always important. Policemen, social workers, regulators, school teachers and the host of other government employees working directly with citizens exercise discretion countless times each day, and in doing so define the true meaning of the public policy. Laws on the books and the emergency proclamations of political leaders are all important indicators of what government wants to do in a crisis, but the discretion exercised by street-level workers, and their professionalism in making their decisions are what really matter to citizens.

The street-level is important for delivering public services and it is also important for defining the nature of government to citizens. It matters not only that the services are delivered, but also how they are delivered. If the street-level employee can engender trust and respect in citizens, then governance becomes easier in the future, and governments may be able to expect more willing compliance by citizens. Given that the average street-level bureaucrat is not the "expert" that has engendered so much animosity and opposition during the crises, they may be more capable of building trust and demonstrating that governments can indeed be effective.

Again, this level of government is always important, and its failures (Baumgartner et al. 2018) are important at any time but may become especially valuable in a time of crisis. For example, having the capacity for contact tracing in public health organizations has been extremely valuable in attempts to control the spread of the virus, and some countries such as South Korea and Germany have been successful in implementing this strategy. Unfortunately, the emphasis on acute care and curative medicine in many countries had eroded public health organizations and their ability to function effectively at the street-level to combat the pandemic.

\section{Bureaucratic politics}

A crisis will also tend to accentuate the internal bureaucratic politics within any institutional setting. Graham Allison's (1971) study of the Cuban missile crisis was the first explication of the bureaucratic politics model, and it has proven useful for understanding how organizations use decision situations as arenas within which they can pursue their self interest. Crises tend to loosen institutionalized patterns among organizations and create greater opportunities for pursuing their interests.

\footnotetext{
5 Mainstreaming health, or "health transversality" has been used to attempt to get decision-makers to recognize the connections between health issues and a host of other policy domains. See (Leppo et al. 2013).
} 
In the United States, for example, there was a good deal of jockeying among organizations such as the CDC, the National Institutes of Health, the Department of Health and Human Services and state agencies over who has or should, control various aspects of the response to the pandemic. These bureaucratic politics has been exacerbated by the politicization of the decision-making that already has been mentioned. At a time at which greater unity and commitment to common goals should be expected, the familiar patterns of bureaucratic politics and turf-fighting (Bardach 1996) have remained central elements of decision-making in government.

But as well as creating opportunities these crises have also created dangers for public organizations playing the bureaucratic politics game. Organizations that have relied at least in part on their positive reputation (Wæraas, and Maor 2015) for success in budgeting and other battles may find any failures in time of crisis to be magnified. From the perspective of the United States, the fall from grace of the Center for Disease Control and Prevention (CDC) is a stark example. (Willman 2020). Several poor decisions tarnished seriously a reputation of competence built over decades.

\section{Planning and anticipation}

By the time a governance problem, and especially a crisis, is recognized, it may already be too late for a government to respond. This need to anticipate problems, whether mundane or actual crisis, therefore leads to thinking about public planning. Planning has a negative connotation in many countries, evoking images of rigidity and unreasonable assumptions about both goals and means to achieve those goals. Some of the antipathy toward planning may reflect the policy styles of countries that prefer to react to problems rather than anticipate them, while in other cases there may be a failure to identify and anticipate the threats that actually are appearing because they do not conform to the plan (Richardson 2017).

Crises also make clear that the old adage the plans are worthless but planning is priceless is a rather wise way to go about the task of governing. The point is that once the crisis actually hits any existing plan is likely not to really match the circumstances being encountered. Von Clausewitz is reputed to have said that every plan is a good one-until the first shot is fired, and that is true for more peaceful planning as well. The Trump administration might have been well advised to have retained the pandemic plans left for them by the Obama administration, but those plans would not have been a guarantee of success.

Planning, therefore, has its dangers for dealing with crises, just as it does for dealing with other governance challenges. The most obvious danger is that the crisis at hand may appear to be the one for which the plan was made, but in reality the resemblance is superficial (See Moynihan and Roberts 2021). Initial reactions to COVID-19, for example, may have been based on SARS which was less lethal and less contagious. Having a hammer means everything looks like a nail, and having a plan for a certain type of emergency will mean that those types of emergencies will be identified more readily. Thus, governing for a crisis, or for ordinary times, 
involves balancing anticipation and foresight with some skpeticism and a capacity for adaptation.

\section{Information}

Following on from the need to anticipate and to plan, governance is also about the capacity to utilize information. Hood (1984) pointed out some years ago that Nodality, or the use of information, is one of the key tools of government. Likewise. Knoepfel (2018) listed information as one of the ten most important resources for policymaking. Given that public policy represents the means through which governments and their allies do attempt to steer the economy and the society-in other words, to govern-information processing is a crucial element for governance at any time.

But information may be especially important for governing in a time of crisis. Crises almost by definition involve incomplete and rapidly changing information so that governors must make the most effective use of what information they have, and attempt to fit it into familiar patterns, or perhaps the patterns of previous crises. Decision-making relative to the COVID-19 crisis, for example, depended in part on information gathered during the threats of the Ebola virus and the Zika virus. That understanding of decision-making in a health care crisis must be complemented by an understanding of information used in less extreme circumstances.

Crisis situations also help to point out that much of the information use programs designed for contemporary governance are based on very large bodies of information and high levels of computational capacity. Policymaking is increasingly influenced by "big data", but that type of richness of information is unlikely to be available for crisis governance. Thus, just as planning involves resilience, the use of information in governance involves the ability to function with only sparse and often conflicting data. As Dror (1986) argued some years ago, government decision-making is often being done in situations of risk and adversity.

\section{Governability}

Finally, and perhaps most importantly, what the crisis has made clear that should also be clear in normal times, is that governance is not entirely a function of governments. Individuals and groups in society also play crucial roles in governing. The extent to which a society is governable through the usual instruments available to the government may affect the outcomes of efforts to govern as much or more as the capacities of the public sector.

The story of the pandemic, and now the availability of the vaccine, in the United States emphasizes the importance of governability, and with that trust. The unwillingness of many people to accept the guidance of public officials on rather simple means of slowing the spread of the virus, and the resistance of millions of people to the idea of being vaccinated will mean that the pandemic will be continue long after it could have been contained. The same problems arise in normal times in a political culture steeped in individualism and resistance of the dictates of the public sector. 
But, as already noted, the same people will excoriate government for its poor performance during the pandemic.

\section{Summary}

The description of some of the key features of governance in ordinary times is intended to demonstrate the ways in which crises can inform and improve governance in those ordinary times, and is also to indicate that governance in crisis should not forget the patterns of more normal times. Further, governing in ordinary times should be conducted with the potential demands of crisis in mind. That attention to the potential crisis may be as simple as considering the levels of capacity that should be maintained even when they may appear excessive. In the case of the current pandemic, for example, how many intensive care beds should hospitals have ${ }^{6}$ And how many ventilators? In normal times many of those beds may be empty and the staff may not be utilized to its fullest, but building capacity for the unforeseen, yet probable, crisis is important for designing governance.

\section{Conclusion}

This discussion of the good, the bad, and the merely ordinary in crisis governance should be seen as the foundation for designing systems of governing. We have a great deal of literature on designing public policy (Peters 2018; Fontaine and Peters 2021) but we have less on designing governance. We think about designing constitutions (Sartori 1997; Goodin 1996) and perhaps we often discuss designing, or at least reforming, administrative systems (Hwang 2018) but attempting to design over-all governance arrangements appears to lie outside the capacity of scholars (but see Dator 2020). This is unfortunate, given the need to shape the capacity of governments and their allies to govern in crises, as well as during more fortunate times.

In the case of these conjoined crises, the most obvious lesson to be learned is that our usual ways of thinking about governance within the familiar silos is often inadequate, and is especially inadequate in crisis. Even in "normal" times policy problems are connected and to be addressed effectively they need to be considered together. Following from that, we should be able to see that solutions to one problem may require also solving others. The interaction of health and economic conditions now is apparent, but there is also an ongoing interaction in which poverty tends to produce poor health which in turn makes moving out of poverty more difficult. Thus, public policy-and governance more generally-must decide how best to intervene to ameliorate these on-going interactions of cause and effect.

But at the same time, we are forced to rethink some aspects of governing, many of the familiar routines and familiar challenges of governing persist. Attempting to

\footnotetext{
${ }^{6}$ Hospitals in the United States, for example, have relatively few hospital beds per capita as compared to other wealthy countries. This is because the economic imperatives of same-day surgery have reduced the need for such beds in ordinary times, and with them also the number of intensive care beds.
} 
govern as if everything has changed is unlikely to produce the types of outcomes required, and may undermine some important elements of governing, Everything is affected by the pandemic, but the centrality of the crisis to the performance of governance tasks varies, The crisis may only help us do the mundane better, rather than so altering our modes of governance that we cannot understand our old world, Indeed, we may only understand the new forms of governing by attempting to understand the old.

\section{Compliance with ethical standards}

Conflict of interest The author declares no conflict of interest.

\section{References}

Abrucio, F. L., et al. (2020). Combating COVID-19 under Bolsonaro's federalism: A case of intergovernmental incoordination. Revista de Administração Pública, 54(4), 663-684.

Allison, G. T. (1971). The essence of decision: Explaining the cuban missile crisis. Boston: Little Brown.

APM Research Lab (2020). The Color of Corona Virus: COVID-19 Deaths by Race and Ethnicity in the US, December 10 https://www.apmresearchlab.org/covid/deaths-by-race

Bardach, E. (1996). Turf barriers to interagency collaboration, in D. F Kettl and H. B. Milward, eds., The State of Public Management (Baltimore, MD: Johns Hopkins University Press).

Barnett, C. (1986). The audit of war. London: Macmillan.

Baumgartner, F. R., Epp, D. A., \& Shoub, K. (2018). Suspect citizens: What 20 million traffic stops tell us about policing and race. Cambridge: Cambridge University Press.

Bellafante, G, (2020). Are we losing a generation of children to remote learning?, New York Times, November 9.

Bouckaert, G., D. Galli, S. Kuhlmann, R. Reiter \& S. van Hecke (2020). 'European coronationalism? A hot spot governing a pandemic crisis', Public Administration Review, COVID-19 Viewpoint, pp.1-9.

Cairney, P. (2016). The politics of evidence-based policy making. London: Palgrave Macmillan.

Chandler, D. C. (2014). Resilience: The governance of complexity. Abingdon: Routledge.

Conlan, T. (2006). From cooperative to opportunistic federalism: Reflections on the half-century anniversary of the commission on intergovernmental relations. Public Administration Review, 66, 663-676.

Cooper, C., \& Block, R. (2007). Disaster: Hurricane katrina and the failure of homeland security. New York: Holt.

Dator, J. (2020). Designing New Forms of Governance. Public Policy Review, 1, 7-23.

Dror, Y. (1986). Policymaking Under Adversity (New Brunswick, NJ: Transaction).

Ehrenreich, B. (2018). Natural causes. New York: Twelve.

Fontaine, G. A., \& Peters, B. G. (2021). Handbook on policy design. Cheltenham: Edward Elgar.

Galvani, A. P., A. S. Parpia, A, Pandey, C. Zimmer, J. G. Kahn \& M. C. Fitzpatrick (2020). The Imperative for Universal Healthcare to Curtail the COVID-19 Outbreak in the USA, EClinical Medicine (The Lancet). https://doi.org/10.1016/j.eclinm.2020.100380

Garrett, L. (2000). The collapse of global public health. New York: Hyperion.

Gaskell, J. \& Stoker, G. (2020). Centralised or multi-level: which governance systems are having a 'good' pandemic? British Policy and Politics at LSE (16 Apr 2020). Blog Entry.

Gillon, S. M. (2018). Why Populism is America's Double-edged Sword, History January 5 https://www. history.com/news/why-populism-in-america-is-a-double-edged-sword

Goodin, R. E. (1996). The theory of institutional design. Cambridge: Cambridge University Press.

Hafner, M., E. Yerushalmi, C. Fays, E. Dufresne \& C. Van Stolk (2020). COVID-19 and the Cost of Vaccine Nationalism (Santa Monica, CA: Rand Corporation).

Hood, C. (1984). The Tools of Government (Chatham, NJ: Chatham House).

Hood, C. (2011). The blame game: Spin, bureaucracy and self-preservation in government. Princeton: Princeton University Press. 
Hwang, K. (2018). Understanding the complexity of administrative reform. International Journal of Organizational Analysis. https://doi.org/10.1108/IJOA-02-2018-1356.

Knoepfel, P. (2018). Public policy resources. Bristol: Policy Press.

Leppo, K., Stahl, T., Wismar, M., Ollila, E., \& Lahtinen, E. (2013). Health in all policies: Prospects and potentials. Helsinki: Ministry of Social Affairs and Health.

Levin, K., Cashore, B., Bernstein, S., \& Auld, G. (2012). Overcoming the tragedy of super wicked problems: Constraining our future selves to ameliorate global climate change. Policy Sciences, 45(2), $123-152$.

Levitsky, S., \& Ziblatt, D. (2018). How democracies die. New York: Broadway Books.

Moynihan, D. \& A. Roberts (2021) Dysfunction by Design: Trumpism as Administrative Doctrine, Public Administration Review, forthcoming

Nassif-Pires, L., L. de Lima Xavier, T. Masterson, M. Nikiforo \& F, Rios-Avila (2020). Pandemic of Inequality. Economics Public Policy Brief Archive Levy Economics Institute.

National Governors Association (2020) State initiatives for small business recovery during the Covid19 economic crisis, December 16, https://www.nga.org/memos/small-business-initiatives-covid19/

New York Times (2019). Finland's basic income trial boost happiness, but not employment

Norris, P., \& Inglehart, R. (2019). Cultural backlash: trump. brexit and the rise of authoritarian populism. Cambridge: Cambridge University Press.

Pacces, A. M., \& Weimer, M. (2020). From diversity to coordination: A European approach to COVID19. European Journal of Risk Regulation, 11, 283-296.

Peters, B. G. (2018). Policy problems and policy design. Cheltenham: Edward Elgar.

Peters, B. G. (2020). Inclusive governance in the era of COVID-19: A search for community. Public Policy Review, 1, 1-6.

Peters, B. G. \& E. J. Grin (forthcoming) Governments' responses to the COVID-19 pandemic: The case of the american federations (Bingley: Emerald).

Rauch, J. (Forthcoming). The constitution of knowledge: A defense of truth (Washington, DC: The Brookings Institution).

Rauch, J. (2018). The constitution of knowledge, The National Interest, Fall. https://www.nationalaffairs .com/publications/detail/the-constitution-of-knowledge

Richardson, J. J. (2017). New governance or old governance: A policy styles perspective, in D. Levi-Faur, ed. Oxford Handbook of Governance (Oxford: Oxford University Press).

Sartori, G. (1997). Comparative Constitutional Engineering: An Inquiry into Structures, Incentives and Outcomes. New York: New York University Press.

Schneider, S. K. (2011). Coping with disaster: Public management in crisis situations. Armonk, NY: M. E. Sharpe.

Vieten, U. M. (2020). The "New Normal" and "Pandemic Populism": The COVID-19 crisis and antihygienic mobilization of the far right. Social Sciences, 9, 165-179.

Wæraas, A., \& Maor, M. (2015). Organizational reputation in the public sector. London: Routledge.

Werron, T., \& Ringe, L. (2020). Pandemic practices part one: Turning "Living Through the COVID-19 Pandemic" into a heuristic tool for sociological theorizing. Sociologic, 14, 55-72.

Willman, D. (2020). The CDC's failed race against COVID-19: A threat underestimated and a test overcomplicated, Washington Post.

Wintour, P. (2021). World's poor need action, not COVID "vaccine nationalism" say experts, The Guardian

Wolf-Forham, S. (2020). Integrating government silos: Local emergency management and public health department collaboration for emergency planning and response. American Review of Public Administration, 50, 560-567. 